\title{
PERSEPSI MASYARAKAT TERHADAP PROGRAM PERCETAKAN SAWAH BARU DI DESA AIR KERING KECAMATAN PADANG GUCI HILIR KABUPATEN KAUR DAN PENGARUHNYA TERHADAP LINGKUNGAN
}

\author{
Reko Sastrawan ${ }^{1)}$, Faiz Barcia ${ }^{2)}$, Damres Uker ${ }^{3)}$ \\ ${ }^{1)}$ Program Pascasarjana Pengelolaan Sumber Daya Alam dan Lingkungan, Fakultas \\ Pertanian, Universitas Bengkulu \\ ${ }^{1)}$ Dinas Pertanian Kabupaten Kaur \\ 2) Jurusan Ilmu Tanah Fakultas Pertanian Universitas Bengkulu \\ ${ }^{3)}$ Jurusan Teknologi Industri Pertanian Fakultas Pertanian Universitas Bengkulu
}

\begin{abstract}
ABSTRAK
Penelitian ini bertujuan untuk mengetahui persepsi masyarakat tentang dampak program percetakan sawah baru terhadap lingkungan serta sosial dan ekonomi. Penelitian ini telah dilakukan dari bulan April 2018. Lokasi penelitian adalah wilayah Percetakan Sawah Baru yang berada di Kecamatan Padang Guci Hilir Desa Air Kering. Dipilihnya wilayah ini sebagai lokasi penelitian karena wilayah ini adalah pilot project perluasan sawah baru di Kabupaten Kaur. Pengumpulan data dilakukan menggunakan angket atau kuisoner serta interview (wawancara mendalam). Hasil penelitian menunjukkan bahwa persentase persepsi petani responden yang sudah melakukan budidaya pada lahan cetak sawah baru terhadap dampak dari program cetak sawah dari segi lingkungan adalah sebesar 72,50\% dengan nilai rata-rata jawaban responden adalah sebesar 3,63 dengan kriteria setuju bahwa program cetak sawah baru berdampak negatif terhadap lingkungan. Sedangkan persentase persepsi petani responden yang belum melakukan budidaya pada lahan cetak sawah baru terhadap dampak dari program cetak sawah dari segi lingkungan adalah sebesar $77,89 \%$ dengan nilai rata-rata jawaban responden adalah sebesar 3,89 dengan kriteria setuju bahwa program cetak sawah baru berdampak negatif terhadap lingkungan.Persentase persepsi petani responden yang sudah melakukan budidaya pada lahan cetak sawah baru terhadap dampak dari program cetak sawah dari segi sosial dan ekonomi adalah sebesar 84,69\% dengan nilai rata-rata jawaban responden adalah sebesar 4,23 dengan kriteria sangat setuju bahwa program cetak sawah baru mampu meningkatkan sosial dan ekonomi petani. Sedangkan persentase persepsi petani responden yang belum melakukan budidaya pada lahan cetak sawah baru terhadap dampak dari program cetak sawah dari segi sosial dan ekonomi adalah sebesar 54,61\% dengan nilai rata-rata jawaban responden adalah sebesar 2,73 dengan kriteria cukup setuju bahwa program cetak sawah baru mampu meningkatkan sosial dan ekonomi petani.
\end{abstract}

Kata kunci : persepsi, cetak sawah dampak lingkungan, dampak sosial dan ekonomi

\section{PENDAHULUAN}

Krisis pangan merupakan isu strategis dunia saat ini, ketidak seimbangan antara peningkatan populasi penduduk dengan ketersediaan lahan pemukiman memunculkan masalah yang menyebabkan adanya alih fungsi lahan, sedangkan kebutuhan pangan meningkat tajam. Akibatnya lahan produktif yang seharusnya digunakan untuk lahan pertanian dikonversi menjadi lahan non pertanian. Hal ini diiringi dengan masalah perubahan iklim yang berdampak terhadap menurunnya produktivitas dan menurunnya kualitas hasil panen (Panudju dkk, 2013).

Salah satu aspek penting dalam 
ketahanan pangan adalah ketersediaan pangan. Penyediaan pengan dapat berasal dari produksi dalam negeri atau dari impor. Sebagai suatu Negara kepulauan dengan penduduk besar maka penyediaan pangan harus semaksimal mungkin berasal dari porduksi dalam negeri (swasembada) dan tidak bergantung kepada pangan impor (Saragih, 2010). Ketahanan pangan sangat terkait dengan aspek kemiskinan. Kemiskinan mempunyai dimensi yang luas, namun yang utama adalah ketidakmampuan masyarakat dalam memenuhi kebutuhan dasar pangan bagi kehidupan yang layak, sehingga pemenuhan kebutuhan pangan merupakan salah satu langkah strategis dalam pengentasan kemiskinan (Saragih, 2010).

Pencetakan sawah merupakan suatu langkah positif dalam menjaga persediaan pangan maupun dapat mencegah kelangkaan pagan atau krisis pangan. Namun demikian, agar program cetak sawah baru berhasil maka harus memperhatikan berbagai faktor. Hasil penelitian Astuti dan Kurniawan (2017) menunjukkan bahwa pemanfaatan sawah hasil Program Pencetan Sawah Baru masih sangat rendah. Faktor yang menyebabakan rendahnya pemanfaatan sawah tersebut bersumber dari dua kesalahan yaitu kesalahan teknis pengerjaan pencekatan sawah dan ketidak tepatan dalam menentukan calon penerima (CP) dan calon lokasi (CL). Menurut Astuti (2016) program pencetakan sawah baru yang menghasilkan areal persawahan yang luas dalam waktu yang bersamaan berpotensi menimbulkan permasalahan yang berkaitan dengan ketersediaan tenaga kerja dan konflik pengaturan air.

Hasil penelitian Manulu dkk (2015) menunjukkan bahwa program pencetakan lahan sawah dari aspek ekonomi dipandang petani positif dari indikator distribusi pemasaran hasil panen, membantu modal mencetak sawah, menambah penghasilan, dan menguntungkan petani. Suandi dkk (2013) menyatakan bahwa pencetakan sawah baru sangat membantu petani untuk memperluas lahan pertanian petani serta memanfaatkan lahan tidur petani untuk melakukan usahatani padi sawah. Hasil penelitian menunjukkan bahwa sikap petani cenderung positif terhadap adanya program pencetakan sawah di Kelurahan Simpang Kecamatan Berbak Kabupaten Tanjung Jabung Timur.

Lokasi pecetakan sawah baru ini, berjarak sekitar $5 \mathrm{~km}$ dari pemukiman di Desa Air Kering II ke arah Barat Laut. Untuk menuju lokasi persawahan, hanya dapat ditempuh dengan jalan kaki atau kendaraan roda dua. Jembatan yang menghubungkan pemukiman Desa Air Kering II dengan lokasi persawahan, masih berupa jembatan gantung yang tidak memungkinkan dilalui kendaraan roda empat; walaupun badan jalan untuk kendaraan roda empat telah dibangun secara swadaya masyarakat dan atau bantuan pemerintah. Penggunaan lahan sepanjang jalan menuju lokasi persawahan, berupa kebun campuran dengan komoditas utamanya karet dan sawit. 


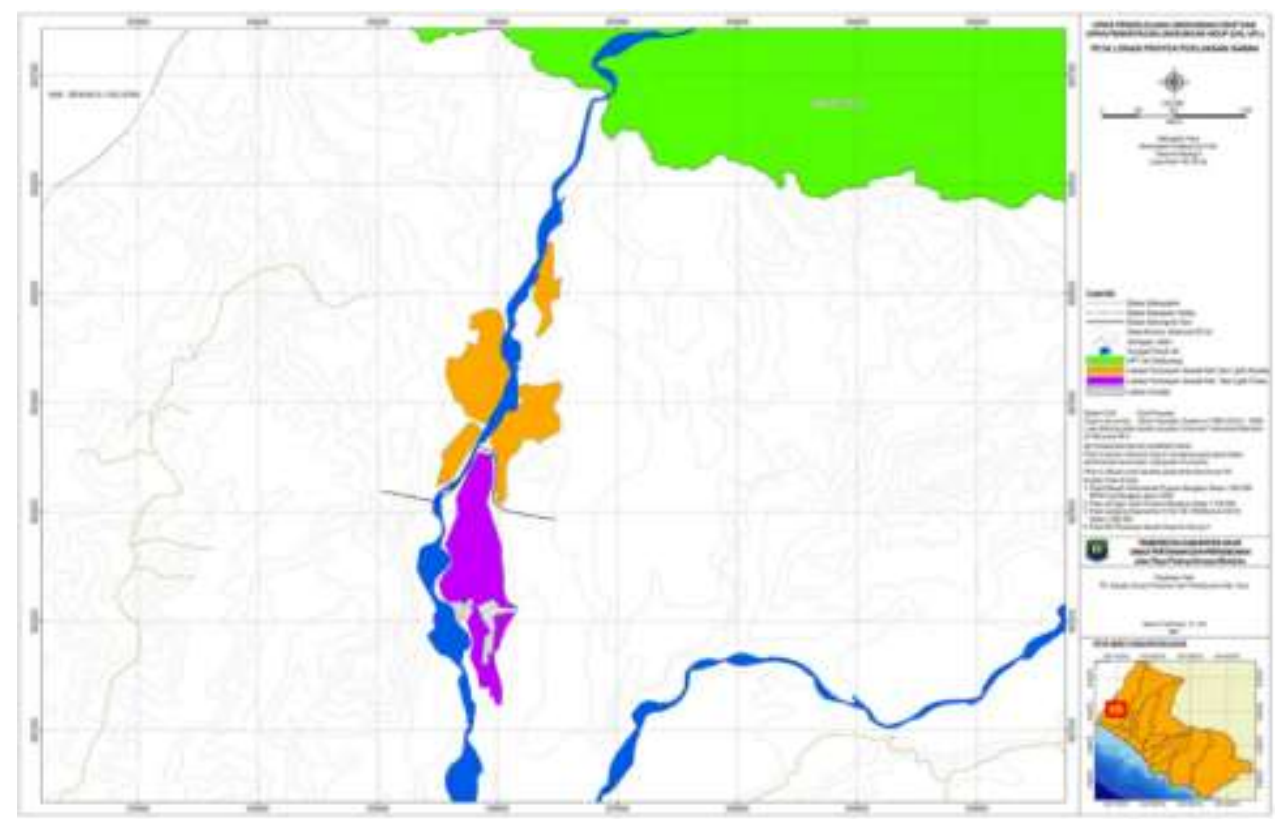

Gambar 1. Peta Pencetakan Sawah di Desa Air Kering II

Lokasi areal persawahan yang dibangun ini sudah jelas dan Bukti kepemilikan lahannya dalam bentuk surat kepemilikan tanah dari pemerintah desa. Setiap warga yang memiliki lahan di lokasi tersebut, telah tercatat sebagai pemilik areal sawahnya dengan luasan yang bervariasi mulai dari $0,5 \quad-2,3$ hektar. Penelitian ini bertujuan untuk :

1. Mengetahui persepsi masyarakat tentang dampak program percetakan sawah baru terhadap lingkungan.

2. Mengetahui persepsi masyarakat tentang dampak program percetakan sawah baru terhadap sosial dan ekonomi.

\section{METODE PENELITIAN}

Penelitian ini telah dilakukan dari bulan April 2018. Lokasi penelitian adalah wilayah Percetakan Sawah Baru yang berada di Kecamatan Padang Guci Hilir Desa Air Kering. Dipilihnya wilayah ini sebagai lokasi penelitian karena wilayah ini adalah pilot project perluasan sawah baru di Kabupaten Kaur.
Populasi dalam penelitian ini adalah masyarakat desa yang menjadi petani padi sawah di Percetakan. Sawah Baru Desa Air Kering Kecamatan Padang Guci Hilir. Penentuan sampel pada penelitian ini menggunakan metode yang dikembangkan oleh Slovin (Kusmayadi, 2000 dalam Yuliansyah, 2008). Jumlah sampel dalam penelitian ini ada 43 responden.

Teknik pengumpulan data primer yang digunakan dalam penelitian ini yaitu menggunakan kuisoner serta wawancara mendalam.

Variabel yang akan diteliti dalam penelitian ini adalah persepsi dan faktorfaktor yang berhubungan dengan persepsi masyarakat terhadap program percetakan sawah baru di desa Air Kering Kecamatan Padang Guci Hilir dan Pengaruhnya terhadap lingkungan. Alat ukur yang digunakan dengan kuisioner menggunakan skala likert. Pertanyaan atau peryataan dijawab oleh responden berbentuk skala likert yang mempunyai gradas dari sangat positif sampai dengan sampai sangat negatif. 
Hasil kuisioner yang disebarkan kepada responden akan dipersentasikan untuk memperoleh nilai rata-rata setiap dimensi berdasarkan hasil pengolahan data. Standar nilai yang digunakan adalah jawaban sangat setuju (SS) dengan nilai 5, karena untuk memperoleh akurasi jawaban mengenai persepsi masyarakat terhadap program percetakan sawah baru di Desa Air Kering Kecamatan Padang Guci Hilir dengan menggunakan analisis kuantitatif penelitian adalah :

Skor penelitian

$\sum$ Responden X Nilai

Skor Ideal

$\Sigma$ Responden X $5 X \sum$ Pertanyaan

Persentase Persepsi (\%)

$$
=\frac{\text { Skor Penelitian }}{\text { Skor Ideal }} \times 100 \%
$$

Metode analisis data yang

digunakan dalam penelitian ini adalah Analisis Diskriftif. Analisis diskriftif digunakan untuk menggambarkan fenomena-fenomena yang terjadi dilapangan berdasarkan variabel-variabel penelitian berdasarkan pengamatan dan persepsi responden. Untuk melihat persepsi responden terhadap variabel yang digunakan dalam penelitian ini digunakan metode rata-rata (mean) dan tabel distribusi frekuensi. Untuk menghitung rata-rata (mean) digunakan rumus (Cooper dan Emory, 1996)

$$
\text { Mean }=\frac{\sum f x}{N}
$$

Dimana :

$\mathrm{F} \quad=$ Frekuensi jawaban responden

$$
\begin{array}{ll}
\mathrm{X} & =\text { Skor jawaban responden } \\
\mathrm{N} & =\text { Jumlah Sampel }
\end{array}
$$

Selanjutnya dihitung juga skala interval jawaban responden, yang bertujuan untuk memudahkan interprestasi hasil dengan rumus (Cooper dan Emory, 1996) :

Skala Interval $=\frac{U-L}{K}$

Dimana :

$\mathrm{U} \quad=$ Skor Jawaban tertinggi

$\mathrm{L} \quad=$ Skor Jawaban terendah

$\mathrm{K}=$ Jumlah Kelas Interval

Maka skala interval yang digunakan dalam penelitian ini adalah sebagai berikut :

Skor jawaban tertinggi (U) $=5$

Skor jawaban terendah (L) $=1$

Jumlah kelas interval $(\mathrm{K}) \quad=5$

Skala interval $=\frac{5-1}{5}=\frac{4}{5}=0,80$

Jadi jarak (skala) setiap kelas interval sebesar 0,80

Dari skala interval tersebut selanjutnya diinterprestasikan kedalam rata-rata jawaban responden dengan kriteria :

Tabel 1. Skala Interval rata-rata jawaban responden

\begin{tabular}{ccc}
\hline NO & Skala Interval Rata-rata & Deskripsi \\
\hline 1 & $1,00-1,79$ & Sangat Tidak Setuju \\
2 & $1,80-2,59$ & Tidak Setuju \\
3 & $2,60-3,39$ & Cukup Setuju \\
4 & $3,40-4,19$ & Setuju \\
5 & $4,20-5,00$ & Sangat Setuju \\
\hline
\end{tabular}

Sumber : Cooper dan Emory (1996) 


\section{HASIL DAN PEMBAHASAN}

Persepsi Masyarakat terhadap Program

Percetakan Sawah Baru dari Segi Lingkungan
Hasil tabulasi jawaban responden yang sudah melakukan budidaya terhadap program cetak sawah baru dari segi lingkungan dapat dilihat pada Tabel 2.

Tabel 2. Hasil tabulasi jawaban responden yang sudah melakukan budidaya terhadap program cetak sawah baru dari segi lingkungan

\begin{tabular}{|c|c|c|c|c|c|}
\hline \multirow{2}{*}{ Pernyataan } & \multicolumn{5}{|c|}{ Jumlah Jawaban Responden } \\
\hline & 1 & 2 & 3 & 4 & 5 \\
\hline $\begin{array}{l}\text { 1. Apakah masyarakat kehilangan ragam tanaman } \\
\text { sumber pangan (durian, talas, petai, aren) }\end{array}$ & - & - & 23 & 1 & - \\
\hline $\begin{array}{l}\text { 2. Apakah masyarakat kehilangan tanaman langka } \\
\text { (gaharu, raflesia, anggrek) }\end{array}$ & - & 23 & 1 & - & - \\
\hline $\begin{array}{l}\text { 3. Apakah masyarakat kehulangan hewan buruan } \\
\text { (kancil, napuh, kijang) }\end{array}$ & - & - & - & 21 & 3 \\
\hline $\begin{array}{l}\text { 4. Apakah masyarakat kehilangan hewan langka } \\
\text { (rusa, harimau, murai batu, jalak) }\end{array}$ & - & & 4 & 20 & - \\
\hline $\begin{array}{l}\text { 5. Apakah masyarakat kehilangan pembasmi alami } \\
\text { (ular pithon, elang, burung) }\end{array}$ & - & & & 11 & 13 \\
\hline $\begin{array}{l}\text { 6. Apakah ada peningkatan hama tanaman (babi, } \\
\text { beruang, tikus) }\end{array}$ & - & - & - & 10 & 14 \\
\hline $\begin{array}{l}\text { 7. Apakah ada peningkatan intensitas banjir dengan } \\
\text { adanya sawah }\end{array}$ & - & - & - & 24 & - \\
\hline $\begin{array}{l}\text { 8. Apakah dengan adanya sawah baru terjadi } \\
\text { peningkatan kekeruhan untuk air minum, mencuci, } \\
\text { dan mandi }\end{array}$ & - & - & 22 & 2 & - \\
\hline $\begin{array}{l}\text { 9. Apakah dengan adanya penambahan jalan } \\
\text { produksi memudahkan akses ke perkebunan petani }\end{array}$ & - & - & - & - & 24 \\
\hline $\begin{array}{l}\text { 10. Apakah penggunaan pupuk dan pestisida } \\
\text { menyebaban pencemaran sungai }\end{array}$ & - & 24 & - & - & - \\
\hline
\end{tabular}

Berdasarkan Tabel 2. terlihat bahwa sebanyak 23 orang responden yang telah melakukan budidaya "cukup setuju", dan 1 orang "setuju" bahwa dengan adanya program cetak sawah baru berdampak pada menghilangnya ragam sumber pangan. Sebanyak 23 responden "tidak setuju", dan 1 orang responden "cukup setuju" bahwa cetak sawah baru menyebabkan hilangnya tanaman langka seperti gaharu, raflesia, dan anggrek. Terdapat 21 responden "setuju" dan 3 responden "sangat setuju" jika cetak sawah baru menyebabkan hewan buruan seperti

kancil, napuh, dan kijang. Sebanyak 4 responden yang "cukup setuju", dan 20 responden "setuju" jika cetak sawah berdampak pada hilangnya hewan langkaseperti rusa, harimau, murai batu, dan jalak. Terdapat 11 responden yang "setuju" dan 13 responden "sangat setuju" bahwa adanya cetak sawah berdampak pada hilangnya pembasmi hama alami 
seperti ular pithon, elang, dan burung. Sebanyak 10 responden "setuju" dan 14 responden "sangat setuju" jika dengan adanya cetak sawah baru menyebabkan peningkatan hama tanaman seperti babi, beruang, tikus. Seluruh responden "setuju" jika program cetak sawah menyebabkan peningkatan intensitas banjir dengan adanya sawah. Terdapat 22 responden yang "cukup setuju" dan 2 responden "setuju" bahwa cetak sawah baru menyebakan meningkatnya kekeruhan untuk air minum, mencuci, dan mandi.
Seluruh responden "sangat setuju" jika dengan adanya program cetak sawah baru akan menyebabkan penambahan jalan produksi memudahkan akses ke perkebunan petani. Serta seluruh responden "tidak setuju" bahwa penggunaan pupuk dan pestisida menyebaban pencemaran sungai.

Hasil tabulasi jawaban kuesioner oleh responden yang belum melakukan budidaya padi tentang dampak program cetak sawah dari segi lingkungan disajikan pada Tabel 3.

Tabel 3. Hasil tabulasi jawaban responden yang belum melakukan budidaya terhadap program cetak sawah baru dari segi lingkungan

\begin{tabular}{|c|c|c|c|c|c|}
\hline \multirow{2}{*}{ Pernyataan } & \multicolumn{5}{|c|}{ Jumlah Jawaban Responden } \\
\hline & 1 & 2 & 3 & 4 & 5 \\
\hline $\begin{array}{l}\text { 1. Apakah masyarakat kehilangan ragam tanaman } \\
\text { sumber pangan (durian, talas, petai, aren) }\end{array}$ & - & - & 17 & 2 & - \\
\hline $\begin{array}{l}\text { 2. Apakah masyarakat kehilangan tanaman langka } \\
\text { (gaharu, raflesia, anggrek) }\end{array}$ & - & 16 & 3 & - & - \\
\hline $\begin{array}{l}\text { 3. Apakah masyarakat kehulangan hewan buruan } \\
\text { (kancil, napuh, kijang) }\end{array}$ & - & - & - & 16 & 3 \\
\hline $\begin{array}{l}\text { 4. Apakah masyarakat kehilangan hewan langka } \\
\text { (rusa, harimau, murai batu, jalak) }\end{array}$ & - & - & - & 16 & 3 \\
\hline $\begin{array}{l}\text { 5. Apakah masyarakat kehilangan pembasmi alami } \\
\text { (ular pithon, elang, burung) }\end{array}$ & - & - & - & 9 & 10 \\
\hline $\begin{array}{l}\text { 6. Apakah ada peningkatan hama tanaman (babi, } \\
\text { beruang, tikus) }\end{array}$ & - & 1 & - & 3 & 15 \\
\hline $\begin{array}{l}\text { 7. Apakah ada peningkatan intensitas banjir dengan } \\
\text { adanya sawah }\end{array}$ & - & 1 & - & 16 & 2 \\
\hline $\begin{array}{l}\text { 8. Apakah dengan adanya sawah baru terjadi } \\
\text { peningkatan kekeruhan untuk air minum, mencuci, } \\
\text { dan mandi }\end{array}$ & - & 1 & - & 14 & 4 \\
\hline $\begin{array}{l}\text { 9. Apakah dengan adanya penambahan jalan produksi } \\
\text { memudahkan akses ke perkebunan petani }\end{array}$ & - & - & 1 & 2 & 16 \\
\hline $\begin{array}{l}\text { 10. Apakah penggunaan pupuk dan pestisida } \\
\text { menyebaban pencemaran sungai }\end{array}$ & - & 1 & 17 & 1 & - \\
\hline
\end{tabular}

Berdasarkan Tabel 3. terlihat bahwa sebanyak 17 responden yang belum melakukan budidaya padia sawah "cukup setuju", dan 2 responden "setuju" bahwa cetak sawah baru menyebabkan kehilangan ragam tanaman sumber pangan seperti durian, talas, petai, aren. Sebanyak 16 responden "tidak setuju", dan 3 orang responden "cukup setuju" bahwa cetak sawah baru menyebabkan hilangnya tanaman langka seperti gaharu, raflesia, dan anggrek. Terdapat 16 responden "setuju" dan 3 responden "sangat setuju" jika cetak sawah baru menyebabkan hewan buruan seperti kancil, napuh, dan kijang. Sebanyak 16 responden yang "setuju", dan 3 responden "sangat setuju" jika cetak sawah berdampak pada hilangnya hewan 
langkaseperti rusa, harimau, murai batu, dan jalak. Terdapat 9 responden yang "setuju" dan 10 responden "sangat setuju" bahwa adanya cetak sawah berdampak pada hilangnya pembasmi hama alami seperti ular pithon, elang, dan burung. Sebanyak 1 responden "tidak setuju" dan 3 responden "setuju", serta 15 rseponden "sangat setuju" jika dengan adanya cetak sawah baru menyebabkan peningkatan hama tanaman seperti babi, beruang, tikus. Terdapat 1 responden "tidak setuju", 16 rseponden "setuju" dan 2 responden "sangat setuju" jika program cetak sawah menyebabkan peningkatan intensitas banjir dengan adanya sawah. Terdapat 1 responden "tidak setuju", 14 rseponden "setuju" dan 4 responden "sangat setuju" bahwa cetak sawah baru menyebakan meningkatnya kekeruhan untuk air minum, mencuci, dan mandi. Terdapat 1 responden "cukup setuju", 2 responden "setuju" dan 16 responden "sangat setuju" jika dengan adanya program cetak sawah baru akan menyebabkan penambahan jalan produksi memudahkan akses ke perkebunan petani. Sebanyak 1 responden "tidak setuju" 17 responden "cukup setuju", dan 1 responden "setuju" bahwa penggunaan pupuk dan pestisida menyebaban pencemaran sungai.

Rangkuman tabulasi persepsi responden baik yang sudah maupun yang belum melakukan budidaya padi sawah tentang dampak program cetak sawah baru terhadap lingkungan disajikan pada Tabel 4.

Tabel 4. Persepsi responden terhadap program cetak sawah baru dari segi lingkungan

\begin{tabular}{lccccc}
\hline Responden & $\begin{array}{c}\text { Skor } \\
\text { Penelitian }\end{array}$ & Skor Ideal & $\begin{array}{c}\text { Persentase } \\
\text { Persepsi }(\%)\end{array}$ & $\begin{array}{c}\text { Rata-rata } \\
\text { Jawaban }\end{array}$ & Kriteria \\
\hline $\begin{array}{l}\text { Sudah } \\
\text { melakukan } \\
\text { budidaya }\end{array}$ & 870 & 1200 & 72,50 & 3,63 & Setuju \\
\hline $\begin{array}{l}\text { Belum } \\
\text { melakukan } \\
\text { budidaya }\end{array}$ & 740 & 950 & 77,37 & 3,87 & Setuju \\
\hline
\end{tabular}

Berdasarkan Tabel 4 terlihat bahwa persentase persepsi petani responden yang sudah melakukan budidaya pada lahan cetak sawah baru terhadap dampak dari program cetak sawah dari segi lingkungan adalah sebesar $72,50 \%$, yang berarti bahwa sebanyak $72,50 \%$ persepsi responden beranggapan bahwa program cetak sawah berdampak negatif terhadap lingkungan. Hal ini diperkuat dengan nilai rata-rata jawaban responden adalah sebesar 3,63 dengan kriteria setuju bahwa program cetak sawah baru berdampak negatif terhadap lingkungan. Sedangkan persentase persepsi petani responden yang belum melakukan budidaya pada lahan cetak sawah baru terhadap dampak dari program cetak sawah dari segi lingkungan adalah sebesar $77,37 \%$, yang berarti bahwa sebanyak $77,37 \%$ persepsi responden beranggapan bahwa program cetak sawah berdampak negatif terhadap lingkungan. Hal ini diperkuat dengan nilai rata-rata jawaban responden adalah sebesar 3,87 dengan kriteria setuju bahwa program cetak sawah baru berdampak negatif terhadap lingkungan. Walaupun kedua jenis responden tersebut memiliki katagori rata-rata jawaban setuju, namun nilai ratarata pada responden yang belum melakukan budidaya pada lahan cetak sawah lebih besar daripada responden yang sudah melakukan budidaya pada lahan cetak sawah. Hal ini mengindikasikan bahwa persepsi responden yang belum melakukan budidaya pada lahan cetak sawah lebih besar beranggapan bahwa program cetak 
sawah memiliki dampak negatif terhadap lingkungan daripada responden yang sudah melakukan budidaya pada lahan cetak sawah.

Perluasan areal pertanian merupakan salah satu bentuk perubahan penggunaan sumberdaya lahan (land-use change) dari bukan lahan pertanian menjadi lahan pertanian (Bapenas, 2010). Pada lokasi penelitian lahan yang digunakan untuk program cetak sawah sawah merupakan lahan tidur berupa rawa yang dimiliki oleh petani. Lahan tersebut merupakan habitat bagi beberapa flora maupun fauna. Pembukaan lahan tersebut secara nyata akan merusak habitat bagi flora dan fauna yang berada pada lahan tidur tersebut. Beberapa dampak yang ditimbulkan diantaranya adalah berkurangnya hewan buruan bagi warga seperti ikan air tawar dan burung, berkurangnya predator hama seperti ular sawah dan burung hantu, dan berkurangnya beberapa jenis tanaman yang bisa dimanfaatkan oleh manusia.

Berdasarkan hasil penelitian maka perlu dilakukan upaya-upaya untuk mengurangi pengaruh buruh dari percetakan sawah. Agar flora dan fauna tidak kehilangan habitatnya secara permanen maka pemerintah perlu membebaskan suatu kawasan sebagai habitat baru bagi flora dan fauna yang sebelumnya menempati lahan tidur yang telah berubah menajdi sawah sebagai habitatnya. Selain itu, perlu dilakukan pelatihan-pelatihan untuk meingkatkan pengetahuan petani dalam kegiatan budidaya pertanian yang ramah dan aman terhadap lingkungan. Beberapa pemahan yang perlu disalurkan ke petani diantaranya adalah tentang cara, dosis dan waktu yang tepat dalam penggunaan pupuk kimia dan pengendalian hama serta penyakit secara kimia. Hal ini dikarenakan penggunaan pupuk dan pengendalian OPT

\section{Persepsi Masyarakat terhadap Program Percetakan Sawah Baru dari Segi Sosial dan Ekonomi}

berbahan kimia yang tidak tepat dosis dan waktunya akan berpotensi tinggi merusak lingkungan.

Hasil penelitian menunjukkan bahwa walupun dampak negatif cetak sawah terhadap lingkungan tidak berpengaruh besar terhadap kehidupan petani, sehingga terdapat responden yang masih melakukan budidaya pada lahan cetak sawah tersebut. Hal ini mengindikasikan bahwa terdapat faktor lain yang berpengaruh terhadap persepsi responden, salah satunya adalah faktor nilai ekonomi dari kegiatan budidaya padi pada lahan cetak sawah baru. Namun demikian, agar kegiatan bercocok tanam padi tidak menimbulkan dampak yang besar terhadap lingkungan, maka diperlukan pengawasan yang intensif dari pemerintah melalui tenaga penyuluh. Peran tenaga penyuluh sangat diperlukan dalam mengidentifikasi, menanggulangi, serta mengendalian faktor-faktor pembatasa dalam budidaya pertanian. Keberadaan tenaga penyuluh akan mempermudah petani dalam mengambil keputusan dan aplikasinya terhadap beberapa upaya dalam meningkatkan produksi padi. Menurut Inten (2017) bahwa penyuluh sangat berperan dalam mengembangkan produktivitas petani dalam usaha taninya. Sesuai dengan tugas pokok penyuluh maka penyuluh harus mampu berperan untuk mengubah perilaku (pengetahuan, sikap dan keterampilan ) petani agar lebih baik lagi dalam usaha taninya. Penyelenggaraan penyuluhan pertanian akan berjalan dengan baik apabila ada persamaan persepsi antara penyuluh dan petani serta pihak-pihak yang berkepentingan. Selain itu Sundari (2015) menyatakan bahwa peran dan fungsi penyuluh yang sangat penting sebagai ujung tombak pemerintah yang bersentuhan langsung dengan petani.

Pengukuran persepsi responden terhadap dampak program cetak sawah baru dari sisi sosial dan ekonomi 
menggunakan kuesioner yang berisi pernyataan-pernyataan yang mengarah bahwa program cetak sawah baru mampu meningkatkan sosial dan ekonomi petani. Hasil tabulasi jawaban kuesioner oleh responden yang sudah melakukan budidaya padi sawah tentang dampak program cetak sawah dari segi sosial dan ekonomi disajikan pada Tabel 5.

Berdasarkan hasil penelitian yang disajikan pada Tabel 5 terlihat bahwa sebanyak 23 responden yang sudah melakukan budidaya padi sawah "setuju" dan 1 responden "sangat setuju" jika cetak sawah sesuai dengan pola usaha masyarakat. Sebanyak 17 responden "setuju" dan 7 responden "sangat setuju" bahwa cetak sawah sesuai keinginan masyarakat. Terdapat 22 responden "setuju" dan 2 responden "sangat setuju" jika cetak sawah dapat meningkatkan adopsi teknologi pertanian. Sebanyak 11 responden "cukup setuju" dan 13 responden "setuju" jika cetak sawah mengubah luas lahan petani. Seluruh responden "sangat setuju" jika cetak sawah meningkatkan pedapatan petani dan kesejahteraan petani sekitar. Seluruh responden "setuju" jika cetak sawah meningkatkan aktivitas ekonomi masyarakat sekitar (adanya rice milling, adanya angkut produksi, adanya mesin perontok) dan memudahkan masyarakat mendapatkan saprodi yang dibutuhkan di lingkungan sekitar.

Tabel 5. Hasil tabulasi jawaban responden yang sudah melakukan budidaya terhadap program cetak sawah baru dari segi sosial dan ekonomi

\begin{tabular}{|c|c|c|c|c|c|}
\hline \multirow{2}{*}{ Pernyataan } & \multicolumn{5}{|c|}{ Jumlah Jawaban Responden } \\
\hline & 1 & 2 & 3 & 4 & 5 \\
\hline $\begin{array}{l}\text { 1. Apakah cetak sawah sesuai dengan pola usaha } \\
\text { masyarakat }\end{array}$ & - & - & - & 23 & 1 \\
\hline 2. Apakah cetak sawah sesuai keinginan masyarakat & - & - & - & 17 & 7 \\
\hline $\begin{array}{l}\text { 3. Apakah cetak sawah dapat meningkatkan adopsi } \\
\text { teknologi pertanian }\end{array}$ & - & - & - & 22 & 2 \\
\hline 4. Apakah cetak sawah mengubah luas lahan petani & - & - & 11 & 13 & - \\
\hline $\begin{array}{l}\text { 5. Apakah cetak sawah meningkatkan pendapatan } \\
\text { petani }\end{array}$ & - & - & - & - & 24 \\
\hline $\begin{array}{l}\text { 6. Apakah cetak sawah meningkatkan kesejahteraan } \\
\text { petani sekitar }\end{array}$ & - & - & - & - & 24 \\
\hline $\begin{array}{l}\text { 7. Apakah cetak sawah meningkatkan aktivitas } \\
\text { ekonomi masyarakat sekitar (adanya rice milling, } \\
\text { adanya angkut produksi, adanya mesin perontok) }\end{array}$ & - & - & - & 24 & - \\
\hline $\begin{array}{l}\text { 8. Apakah adanya cetak sawah memudahkan } \\
\text { masyarakat mendapatkan saprodi yang dibutuhkan } \\
\text { di lingkungan sekitar }\end{array}$ & - & - & - & 24 & - \\
\hline
\end{tabular}

Hasil tabulasi jawaban kuesioner oleh responden yang belum melakukan budidaya padi tentang dampak program cetak sawah dari segi sosial dan ekonomi disajikan pada Tabel 6. Berdasarkan hasil penelitian yang disajikan pada Tabel 5 terlihat bahwa seluruh responden yang belum melakukan budidaya padi sawah "setuju" jika cetak sawah sesuai dengan pola usaha masyarakat. Namun seluruh responden "sangat tidak setuju" bahwa cetak sawah sesuai keinginan masyarakat. Terdapat 13 responden "tidak setuju" dan 6 responden "cukup setuju" jika cetak sawah dapat meningkatkan adopsi teknologi pertanian. Seluruh responden "sangat setuju" jika cetak sawah mengubah luas lahan petani. Terdapat 1 
responden "sangat tidak setuju", 15 responden "tidak setuju" dan 3 responden "cukup setuju" jika cetak sawah meningkatkan pedapatan petani dan kesejahteraan petani sekitar. Sebanyak 2 responden "sangat tidak setuju", 10 responden "tidak setuju", 5 responden "cukup setuju", dan 1 responden "sangat setuju" jika cetak sawah meningkatkan aktivitas ekonomi masyarakat sekitar (adanya rice milling, adanya angkut produksi, adanya mesin perontok). Sebanyak 2 responden "sangat tidak setuju", 9 responden "tidak setuju", 6 responden "cukup setuju", dan 2 responden "sangat setuju" jika adanya cetak sawah memudahkan masyarakat mendapatkan saprodi yang dibutuhkan di lingkungan sekitar.

Tabel 6. Hasil tabulasi jawaban responden yang belum melakukan budidaya terhadap program cetak sawah baru dari segi sosial dan ekonomi

\begin{tabular}{|c|c|c|c|c|c|}
\hline \multirow{2}{*}{ Pernyataan } & \multicolumn{5}{|c|}{ Jumlah Jawaban Responden } \\
\hline & 1 & 2 & 3 & 4 & 5 \\
\hline $\begin{array}{l}\text { 1. Apakah cetak sawah sesuai dengan pola usaha } \\
\text { masyarakat }\end{array}$ & - & - & - & 19 & - \\
\hline 2. Apakah cetak sawah sesuai keinginan masyarakat & 19 & - & - & - & - \\
\hline $\begin{array}{l}\text { 3. Apakah cetak sawah dapat meningkatkan adopsi } \\
\text { teknologi pertanian }\end{array}$ & - & 13 & 6 & - & - \\
\hline 4. Apakah cetak sawah mengubah luas lahan petani & - & - & - & - & 19 \\
\hline $\begin{array}{l}\text { 5. Apakah cetak sawah meningkatkan pendapatan } \\
\text { petani }\end{array}$ & 1 & 15 & 3 & - & - \\
\hline $\begin{array}{l}\text { 6. Apakah cetak sawah meningkatkan kesejahteraan } \\
\text { petani sekitar }\end{array}$ & 1 & 15 & 3 & - & - \\
\hline $\begin{array}{l}\text { 7. Apakah cetak sawah meningkatkan aktivitas } \\
\text { ekonomi masyarakat sekitar (adanya rice milling, } \\
\text { adanya angkut produksi, adanya mesin perontok) }\end{array}$ & 2 & 10 & 5 & - & 1 \\
\hline $\begin{array}{l}\text { 8. Apakah adanya cetak sawah memudahkan } \\
\text { masyarakat mendapatkan saprodi yang dibutuhkan } \\
\text { di lingkungan sekitar }\end{array}$ & 2 & 9 & 6 & - & 2 \\
\hline
\end{tabular}

Rangkuman tabulasi persepsi responden baik yang sudah maupun yang belum melakukan budidaya padi sawah tentang dampak program cetak sawah baru terhadap sosial dan ekonomi disajikan pada Tabel 7.

Tabel 7. Persepsi responden terhadap program cetak sawah baru dari segi sosial dan ekonomi

\begin{tabular}{lccccc}
\hline Responden & Skor Penelitian & Skor Ideal & $\begin{array}{c}\text { Persentase } \\
\text { Persepsi (\%) }\end{array}$ & $\begin{array}{c}\text { Rata-rata } \\
\text { Jawaban }\end{array}$ & Kriteria \\
\hline $\begin{array}{l}\text { Sudah } \\
\text { melakukan } \\
\text { budidaya }\end{array}$ & 813 & 960 & 84,69 & 4,23 & Sangat Setuju \\
\hline $\begin{array}{l}\text { Belum } \\
\text { melakukan } \\
\text { budidaya }\end{array}$ & 415 & 760 & 53,55 & 2,67 & Cukup Setuju \\
\hline
\end{tabular}

Hasil penelitian menunjukkan bahwa persentase persepsi petani responden yang sudah melakukan budidaya pada lahan cetak sawah baru terhadap dampak dari program cetak sawah dari segi sosial dan ekonomi adalah sebesar 84,69\%, yang berarti bahwa sebanyak $84,69 \%$ persepsi responden beranggapan bahwa program cetak sawah mampu meningkatkan sosial dan ekonomi petani. Hal ini diperkuat 
dengan nilai rata-rata jawaban responden adalah sebesar 4,23 dengan kriteria sangat setuju bahwa program cetak sawah baru mampu meningkatkan sosial dan ekonomi petani. Hasil penelitian Siata dan Sativa (2013) menunjukkan bahwa program pencetakan sawah baru sangat membantu petani untuk memperluas lahan pertanian petani serta memanfaatkan lahan tidur petani untuk melakukan usahatani padi sawah. Hasil penelitian menunjukkan bahwa sikap petani cenderung positif terhadap adanya program pencetakan sawah di Kelurahan Simpang Kecamatan Berbak Kabupaten Tanjung Jabung Timur.

Program pencetakan lahan sawah dari aspek ekonomi dipandang petani positif dari indikator distribusi pemasaran hasil panen, membantu modal mencetak, dipandang menjamin kehidupan petani dari indikator aman memenuhi kebutuhan pangan sehari-hari, nyaman dalam melengkapi alsintan dalam berusahatani, mutu beras yang dikonsumsi lebih baik, meningkatkan taraf hidup, meningkatkan rasa percaya diri, dipandang menciptakan dinamika kelompok tani hingga mencapai terminologi yang baik untuk petani, serta dipandang meningkatkan pengetahuan dan ketrampilan petani dalam berusahatani tanaman padi (Manulu dkk, 2015)

Disisi lain, persentase persepsi petani responden yang belum melakukan budidaya pada lahan cetak sawah baru terhadap dampak dari program cetak sawah dari segi sosial dan ekonomi adalah sebesar $53,55 \%$, yang berarti bahwa hanya sebanyak 53,55\% persepsi responden beranggapan bahwa program cetak sawah mampu meningkatkan sosial dan ekonomi petani. Hal ini diperkuat dengan nilai ratarata jawaban responden adalah sebesar 2,67 dengan kriteria cukup setuju bahwa program cetak sawah baru mampu meningkatkan sosial dan ekonomi petani. Persepsi masyarakat ini diduga karena terdapat beberapa faktor yang berpotensi menyebabkan rendahnya produksi atau gagal panen ketika mereka melakukan budidaya pada sawah baru tersebut. Faktor-faktor tersebut diantaranya irigasi, ancaman gangguan hama, dan teknologi budidaya.

Keterserdiaan, efektivitas dan efisiensi infarstruktur jaringan irigasi yang memadai adalah sangat dibutuhkan. Hal tertsebut dikarenakan keberadaan air di negara kita sangat khas, melimpah pada pada bulan-bulan basah karena curah hujan yang tinggi dan kekurangan pada bulankering (Direktorat Pengelolaan Air, 2014). Belum terdapatnya aliran irigasi buatan yang menjamin air selalu tersedia diduga menjadi salah satu faktor. Menurut Hasibuah (2010) kecukupan air merupakan faktor utama dan merangsang pertumbuhan tanaman yang lebih baik sehingga didapatkan produksi tanaman yang optimum. Salah satu dari bagian system pendukung tersebut ketersediaan air dalam jumlah yang cukup, waktu dan tepat, bila tidak proses pertumbuhan dan perkembangnnya akan terganggu yang berakibat produksi baik secara kuantitas maupun kualitas rendah.

Selain itu hasil berdasarkan hasil wawancara langsung dengan responden, potensi serangan hama terutama burung menjadi satu faktor yang menyebabkan responden belum melakukan budidaya pada lahan cetak sawah. Sejalan dengan hasil penelitian Manulung dkk (2010) penanggulan hama pada program pencetakan lahan sawah petani berpandangan negatif karena pada kelompok tani Junika Hasnizar maupun Sumber Makmur masih kesulitan dengan hama burung ketika panen dan pada penanggulan gulma petani masih kesulitan dengan tunggul yang masih tersisa pada lahan.

Berdasarkan permasalahan tersebut maka pemerintah perlu melakukan upayaupaya agar kegiatan budidaya padi pada sawah cetakan baru lebih bernilai ekonomi. Sosialisai dan pelatihan terhadap teknologi baru oleh pemerintah sangat diperlukan oleh petani. Hal ini karena 
sawah bukaan baru tidak secara otomatis menjadi sawah yang siap digarap, tetapi memerlukan berbagai upaya khusus, baik dari aspek teknis maupun non teknis. Aspek teknis dikembangkan dengan melakukan berbagai ujicoba teknologi melalui suatu pengkajian secara bertahap, sedang non teknis berkaitan dengan mempersiapkan kelembagaannya. Dalam rangka pengembangan teknologi, peran PPL di BPP sangat strategis. Untuk lebih mengoptimalkan perannya perlu dilakukan satu upaya, yaitu meningkatkan kapasitas PPL yang bersangkutan dalam memahami teknologi rakitan BPTP melalui suatu pelatihan. Dalam pelatihan, anggota tim pengkaji bertindak sebagai fasilitator dan penyampai informasi teknologi yang dikembangkan oleh BPTP. Kegiatan seperti ini dilakukan bersamaan dengan pertemuan mingguan PPL di BPP. Selain memanfaatkan PPL, petani kooperator juga diberi tugas untuk memperkenalkan teknologi kepada petani sekitar yang bukan kooperator. Seorang kooperator membina minimal tiga orang petani lain sebagai petani pengembang agar ikut menerapkan teknologi hasil kajian dan selanjutnya secara bertahap juga membina petani yang lain.

Melalui mekanisme seperti ini petani kooperator berperan sebagai penyuluh pertanian swakarsa, rekan kerja PPL serta sebagai pendamping teknisi lapangan dalam melakukan pembinaan kepada petani. Kepada setiap petani pengembang yang menerapkan paket teknologi yang dikaji, diberi stimulan berupa benih dan pupuk. Bantuan pupuk $\mathrm{P}$ dan $\mathrm{K}$ tidak penuh tetapi hanya setengah dari dosis yang diperlukan, sedangkan kebutuhan sarana produksi lainnya dipenuhi sendiri oleh petani pengembang.
Berdasarkan hasil penelitian dapat disimpulkan bahwa :

1. Persentase persepsi petani responden yang sudah melakukan budidaya pada lahan cetak sawah baru terhadap dampak dari program cetak sawah dari segi lingkungan adalah sebesar 72,50\% dengan nilai rata-rata jawaban responden adalah sebesar 3,63 dengan kriteria setuju bahwa program cetak sawah baru berdampak negatif terhadap lingkungan. Sedangkan persentase persepsi petani responden yang belum melakukan budidaya pada lahan cetak sawah baru terhadap dampak dari program cetak sawah dari segi lingkungan adalah sebesar $77,89 \%$ dengan nilai rata-rata jawaban responden adalah sebesar 3,89 dengan kriteria setuju bahwa program cetak sawah baru berdampak negatif terhadap lingkungan.

2. Persentase persepsi petani responden yang sudah melakukan budidaya pada lahan cetak sawah baru terhadap dampak dari program cetak sawah dari segi sosial dan ekonomi adalah sebesar $84,69 \%$ dengan nilai rata-rata jawaban responden adalah sebesar 4,23 dengan kriteria sangat setuju bahwa program cetak sawah baru mampu meningkatkan sosial dan ekonomi petani. Sedangkan persentase persepsi petani responden yang belum melakukan budidaya pada lahan cetak sawah baru terhadap dampak dari program cetak sawah dari segi sosial dan ekonomi adalah sebesar 54,61\% dengan nilai rata-rata jawaban responden adalah sebesar 2,73 dengan kriteria cukup setuju bahwa program cetak sawah baru mampu meningkatkan sosial dan ekonomi petani.

\section{KESIMPULAN}

\section{DAFTAR PUSTAKA}



Astuti, N.B, dan B. Kurniawan. 2017. Analisis Pemanfaatan Program Pencetakan Sawah Baru (Kasus Di Nagari Siguhung, Kecamatan Lubuk Basung, Kabupaten Agam, Sumatera Barat). Prosiding Seminar Nasional Lahan Suboptimal "Pengembangan Ilmu dan Teknologi Pertanian Bersama Petani Lokal untuk Optimalisasi Lahan Suboptimal" Palembang 1920 Oktober 2017

Astuti, N, B., Wahyuni, I., Edwin. 2016. Potensi Masalah Dalam Pelaksanaan Program Pencetakan Sawah Baru: Studi kasus di Nagari Tanjung Kaling Kecamatan Kamang Baru Kabupaten Sijunjung, Sumatera Barat. Di dalam: Joko $\mathrm{T}$ et al (eds), Peranan Hasil penelitian Pertanian dalam Mewujudkan Kedaulatan Pangan untuk Kesejahteraan Petani.

Prosiding Seminar Nasional Hasil Penelitian Pertanian VI 2016 Fakultas Pertanian UGM; Yogyakarta.

Badan Pusat Statistik. 2016. Kaur Dalam Angka 2015. BPS Kabupaten Kaur.

Bapenas. 2010. Rencana Kebijakan

Strategis Perluasan Areal Pertanian Baru.

Budiartinmgsih, R., Y. Maulida, danTaryono. 2010. Faktor-faktor yang mempengaruhi peningkatan pendapatan keluarga petani melalui sektor informal di Desa Kedaburapat, Kecamatan Rangsang Barat, Kabupaten Bengkalis.Jurnal ekonomi. 18(1) : 79-93

Bulog. 2014. Laporan Manajemen

Tahunan. Jakarta

Daniel, Mohar. 2004. Pengantar Ekonomi pertanian. Jakarta: PT Bumi Aksara

Direktorat Pengelolaan Air, Kementrian Pertanian. 2014. Pedoman Teknis Pemeliharaan Jaringan Irigasi.
Direktorta Pengelolaan Air, Kementrian Pertanian, Jakarta

Donald. R. Cooper dan William Emory. 1996. Metode Penelitian Bisnis. Jilid I. Erlangga. Jakarta

Hasibuan, SH. 2010. Analisa kebutuhan air irigasi daerah irigasi sawah Kabupaten Kampar. Jurnal Aptek. 3(1) : 97-101

Inten S, D Elviana, dan B.R Nover. 2017. Peranan Penyuluh Pertanian Dalam Peningkatan Pendapatan Petani Komoditas Padi Di Kecamatan Tanjungselor Kabupaten Bulungan Kalimantan Utara. Jurnal AGRIFOR. 16(1) : 103-107

Irawan, B. 2003. Konversi Lahan Sawah di Jawa dan Dampaknya Terhadap Produksi Padi, Ekonomi Padi dan Beras Indonesia. Badan Litbang Pertanian.

Irawan, B. 2005. Konversi Lahan Sawah. Potensi, Dampak, Pola Pemanfaatannya dan Faktor Determinan. Badan Litbang Pertanian.

Kementerian Pertanian. 2016. Pedoman Teknis Perluasan Sawah Baru. Ditjen PSP. Jakarta

Manalu. C., I. Sardi dan Elwamendri. 2015. Persepsi petani padi sawah terhadap program pencetakan lahan sawah di desa singkep kec. Muara Sabak Barat Kabupaten Tanjung Jabung Timur. Sosio Ekonomika Bisnis. 18(1) : 19-29

Manyamsari I, dan Mujiburrahmad. 2014.Karakteristik petani dan hubungannya dengan kompetensi petani lahan sempit. Agrisep 15(2): 58-74.

Riduwan. 2010. Metode dan Teknik Menyusun Tesis. Cetakan Kesepuluh. Alfabeta. Bandung

Saadah S. 1990. Masyarakat petani, matapencaharian sambilan dan kesempatan kerja di Kelurahan Cakung Timur, Daerah Khusus Ibukota Jakarta. Departemen Pendidikan dan Kebudayaan. 
P-ISSN: 2302- 6715

E-ISSN: 2654- 7732

Direktur Jenderal

Kebudayaan. Direktorat Sejarah dan Nilai Tradisional. Proyek Inventarisasi dan Pembinaan Nilai-nilai Budaya

Sentana, S. 2013. Faktor-Faktor yang Mempengaruhi

Produktivitas Pekerja Pada

Industri Kerajinan Sanggah Di Desa Jehem Kabupaten Bangli. Jurnal Ekonomi Pembangunan. 2(1) : $1-9$

Siata, R. Dan F. Sativa. 2013. Sikap Petani Terhadap Program

Pencetakan Sawah Baru Di
Kelurahan Simpang Kecamatan Berbak Kabupaten Tanjung Jabung Timur. Prosiding Seminar Nasional. Pekan Baru

Sugiyono. 2009. Metode Penelitian Kuantitatif dan Kualitatif. Alfabeta. Bandung.

Sundari, Tri. 2015. Analisis Biaya dan Pendapatan Usaha Tani Wortel di Kabupaten Karanganyar. Jurnal SEPA. Volume 7 (2) : 119-126

UKL-UPL Perluasan Sawah Baru. 2016. Dinas Pertanian Kabupaten Kaur. 